\title{
Clinical significance of autoantibodies to p53 protein in patients with autoimmune liver diseases
}

\author{
Takashi Himoto MD PhD¹, Hirohito Yoneyama MD PhD², Kazutaka Kurokohchi MD PhD², Michio Inukai MD PhD, \\ Hisashi Masugata MD PhD¹, Fuminori Goda MD PhD¹, Reiji Haba MD PhD³, Seishiro Watanabe MD PhD, \\ Shoichi Senda MD PhD1, Tsutomu Masaki MD PhD²
}

T Himoto, H Yoneyama, K Kurokohchi, et al. Clinical significance of autoantibodies to $\mathrm{p} 53$ protein in patients with autoimmune liver diseases. Can J Gastroenterol 2012;26(3):125-129.

BACKGROUND: Autoantibodies to p53 (anti-p53) are rarely present in the sera of patients with autoimmune diseases or the sera of patients with malignancies.

OBJECTIVE: To examine the prevalence of anti-p53 in patients with autoimmune liver disease including autoimmune hepatitis (AIH), primary biliary cirrhosis (PBC), AIH/PBC overlap syndrome (AIH/ $\mathrm{PBC} O S$ ) and primary sclerosing cholangitis (PSC), and to determine the clinical significance of anti-p53 in autoimmune liver diseases.

METHODS: Forty patients with AIH, 41 patients with PBC, eight patients with AIH/PBC OS and five patients with PSC were enrolled. Anti-p53 and antibodies to double-stranded DNA (anti-ds-DNA) were analyzed using commercially available ELISA kits. Demographic, laboratory and histological data were compared between the AIH groups seropositive and seronegative for anti-p53.

RESULTS: Six of $40(15.0 \%)$ patients with AIH and four of eight (50.0\%) patients with AIH/PBC OS were positive for anti-p53. One of $41(2.4 \%)$ patients with PBC was also positive for anti-p53, but all five patients with PSC were negative, indicating a significantly higher prevalence of anti-p53 in patients with $\mathrm{AIH}$ or AIH/PBC OS compared with patients with PBC. None of the AIH patients positive for anti-p53 progressed to hepatic failure or relapsed after immunosuppressive treatment. Titres of anti-ds-DNA in patients with AIH and AIH/PBC OS significantly correlated with titres of anti-p53 ( $r=0.511$; $\mathrm{P}=0.0213)$.

CONCLUSION: The emergence of anti-p53 is likely to be useful for discriminating AIH or AIH/PBC OS from PBC and helpful for predicting favourable prognoses in patients with AIH. DNA damage may trigger the production of anti-p53 in patients with $\mathrm{AIH}$ or $\mathrm{AIH} / \mathrm{PBC}$ OS.

Key Words: Antibodies to ds-DNA; Antibodies to p53; Autoimmune hepatitis; Primary biliary cirrhosis

\section{La signification clinique des autoanticorps de la protéine $\mathrm{p} 53 \mathrm{che} z$ les patients ayant une maladie hépatique auto-immune}

HISTORIQUE : Les autoanticorps de la protéinep53 (anti-p53) sont rarement présents dans le sérum des patients ayant une maladie autoimmune ou des patients atteints d'une tumeur maligne.

OBJECTIF : Examiner la prévalence d'anti-p53 chez les patients ayant une maladie hépatique auto-immune, y compris l'hépatite auto-immune (HAI), la cirrhose biliaire primitive (CBP), le syndrome de chevauchement de l'HAI et de la CBP (SC HAI-CBP) et la cholangite sclérosante primitive (CSP), et déterminer la signification clinique de l'anti-p53 en présence de maladies hépatiques auto-immunes.

MÉTHODOLOGIE : Quarante patients ayant une HAI, 41 patients ayant une CBP, huit patients ayant un SC HAI-CBP et cinq patients ayant une CSP ont participé à l'étude. Les chercheurs ont analysé les anti-p53 et les anticorps anti-ADN double brin (anti-ADN-db) au moyen de trousses ELISA commerciales. Ils ont comparé les données démographiques, histologiques et de laboratoire avec les groupes d'HAI séropositifs et séronégatifs aux anti-p 53 .

RÉSULTATS : Six des 40 patients (15,0\%) ayant une HAI et quatre des huit patients $(50,0 \%)$ ayant un SC HAP-CBP étaient positifs aux anti-p53. Un des 41 patients $(2,4 \%)$ ayant une CBP était également positif aux anti-p53, mais les cinq patients ayant une CSP y étaient négatifs, ce qui indique une prévalence significativement plus élevée d'anti-p53 chez les patients ayant une HAI ou un SC HAP-CBP que chez ceux ayant une CBP. Aucun des patients ayant une HAI qui étaient positifs aux anti-p53 n'a vu son état se détériorer en insuffisance hépatique ou n'a rechuté après le traitement immunosuppressif. Les titres d'anti-ADN-db des patients ayant une HAI et un SC HAP-CBP étaient significativement corrélés avec ceux des anti-p53 $(\mathrm{r}=0,511 ; \mathrm{P}=0,0213)$.

CONCLUSION : L'émergence d'anti-p53 est probablement utile pour discriminer l'HAI et le SC HAP-CBPde la simple CBP et pour prédire les pronostics favorables chez les patients ayant une HAI. Les dommages à l'ADN déclenchent peut-être la production d'anti-p53 chez les patients ayant une HAI ou un SC HAI-CBP.

titres of anti-p53 is likely to indicate a poor prognosis or short survival in patients with HCC (9). Anti-IMPs and anti-p53 appear to predict the development of HCC in patients with hepatitis $\mathrm{C}$ virus-related chronic liver disease (8).

On the other hand, anti-p53 is rarely present in the sera of patients with autoimmune diseases including systemic lupus erythematosus (SLE) (10), rheumatoid arthritis (11), dermatomyositis (12), autoimmune thyroiditis (13) and type 1 diabetes mellitus (14). However, there are few reports on anti-p53 in autoimmune liver diseases such as autoimmune hepatitis (AIH) and primary biliary cirrhosis (PBC) (15). Therefore, the clinical relevance of circulating anti-p53 remains uncertain. The primary purposes of the present study were to examine the prevalence of anti-p53 and to reveal the clinical relevance of in the sera of patients with $\operatorname{HCC}(7,8)$. The development of positive

\footnotetext{
${ }^{1}$ Department of Integrated Medicine; ${ }^{2}$ Department of Gastroenterology and Neurology; ${ }^{3}$ Department of Diagnosis Pathology, Kagawa University School of Medicine; ${ }^{4}$ Department of Internal Medicine, Kagawa Prefectural Central Hospital, Kagawa, Japan

Correspondence and reprints: Dr Takashi Himoto, Department of Integrated Medicine, Kagawa University School of Medicine, 1750-1, Ikenobe,

Miki-Cho, Kita-Gun, Kagawa 761-0793, Japan. Telephone 81-87-891-2349, fax 81-87-864-4631, e-mail thimoto@med.kagawa-u.ac.jp

Received for publication June 12, 2011. Accepted July 2, 2011
} 


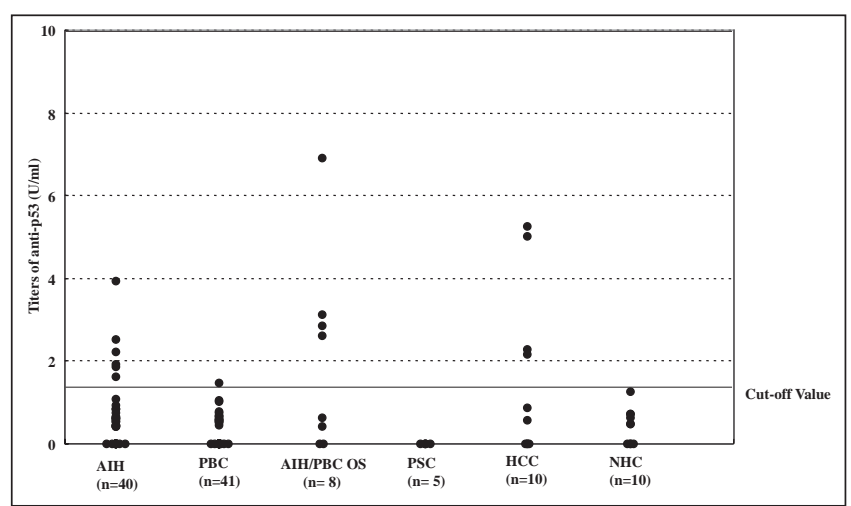

Figure 1) Distribution of anti-p53 titres in each group of patients with autoimmune liver disease and in the comparison groups. AIH Autoimmune hepatitis; HCC Hepatocellular carcinoma; NHC Normal healthy controls; OS Overlap syndrome; PBC Primary biliary cirrhosis; PSC Primary sclerosing cholangitis

anti-p53 in patients with autoimmune liver diseases including $\mathrm{AIH}$, $\mathrm{PBC}, \mathrm{AIH} / \mathrm{PBC}$ overlap syndrome (AIH/PBC OS) and primary sclerosing cholangitis (PSC).

\section{METHODS}

\section{Study population}

Forty patients with type $1 \mathrm{AIH}, 41$ patients with $\mathrm{PBC}$, eight patients with $\mathrm{AIH} / \mathrm{PBC} \mathrm{OS}$ and five patients with PSC were randomly selected among patients admitted to the Hospital of Kagawa University School of Medicine (Kagawa, Japan) between 1998 and 2010. Informed consent was obtained from each patient enrolled in the present study. The clinical diagnosis of type $1 \mathrm{AIH}$ was based on the scoring system proposed by the International Autoimmune Hepatitis Group (16). All of these patients fulfilled the criteria for 'definite' AIH. The diagnosis of PBC was performed based on the internationally accepted criteria for PBC (17). The patients who fulfilled the Paris Criteria (18) at presentation were defined as having $\mathrm{AIH} / \mathrm{PBC} \mathrm{OS}$. The diagnosis of PSC was based on the presence of cholestatic liver enzyme abnormalities combined with typical findings on endoscopic retrograde cholangiography, including diffuse narrowing, irregularity, and budding of the extra- and intra-hepatic bile ducts (19). Ten patients with HCC and 10 normal healthy controls (NHC) were also enrolled as comparison groups in the study.

\section{Demographic assessments}

Age and sex at enrollment were recorded for all of the patients. Onset patterns, concurrent extrahepatic autoimmune disease, progression to hepatic failure, development of HCC, response to immunosuppressive treatments including corticosteroid and/or azathioprine, and relapse after treatment were also investigated in patients with AIH. Onset patterns of AIH were divided into three categories: acute, chronic and fulminant onset. Acute onset was defined as acute presentation of the disease without any history of liver dysfunction. Chronic onset was defined as fluctuating serum alanine aminotransferase (ALT) levels for at least six months in the enrolled AIH patients. Fulminant onset was defined as an onset in the enrolled AIH patients who fulfilled the criteria for fulminant hepatitis.

\section{Laboratory assessments}

Liver function tests, including serum ALT, total bilirubin (T-Bil), immunoglobulin ( Ig) G levels and antinuclear antibodies (ANA) were examined in the enrolled $\mathrm{AIH}$ patients. In addition to these biochemical and immunological tests, serum alkaline phosphatase (ALP) and IgM levels, as well as antimitochondrial antibodies (AMA) were also analyzed in patients with AIH/PBC OS. ANA were determined by the indirect immunofluorescence method using HEp-2 cells as substrates. Seropositivity for ANA was defined as titres of 1:40 or higher. AMA levels were measured using commercially available ELISA kits (MESACUP-2 TEST Mitochondria M2; Normal range $<7$ Index [Medical and Biological Laboratories Co, Ltd, Japan]). Anti-p53 levels were also determined using commercially available ELISA kits (MESACUP anti-p53 TEST, Medical and Biological Laboratories Co, Ltd, Japan). The autoantibodies recognize both the carboxy-terminal DNA-binding domain of $\mathrm{p} 53$ and the aminoterminus of the p53 molecule (20). The cut-off value for this autoantibody was set at $1.3 \mathrm{U} /$ $\mathrm{mL}$. Antibodies to double-stranded DNA (anti-ds DNA) were also analyzed using a commercially available ELISA kit (MESACUP DNA-2 TEST-ds, Medical and Biological Laboratories Co, Ltd, Japan). The cut-off value for the antibody was set at $12 \mathrm{IU} / \mathrm{mL}$.

\section{Histological and immunohistochemical assessments}

Liver tissue specimens were obtained at biopsy under ultrasound guidance using 16-gauge needles. The tissue samples were fixed in $10 \%$ formalin and embedded in paraffin. Tissue sections were stained with hematoxylin and eosin. The severity of fibrosis and necroinflammation in the liver were evaluated in accordance with the histological activity index (HAI) scores established by Knodell et al (21).

The expression of $\mathrm{p} 53$ protein and caspase-3, the hallmark of apoptosis, in liver tissue was examined using immunohistochemical techniques. Briefly, tissue sections were deparaffinized; the specimen was subsequently washed with phosphate-buffered saline (PBS) and incubated with mouse anti-human monoclonal antibody to p53 (Leica Microsystems GmbH, Germany) and caspase-3 (Santa Cruz Biotechnology, Inc, USA) as the primary antibody. After washing with PBS, the tissue section was incubated with biotinylated goat antimouse polyclonal antibody. Thereafter, colour was developed with diaminobenzine (DAB) substrate. Counterstaining was performed with hematoxylin.

\section{Statistical analysis}

Data are presented as mean \pm SD. The Mann-Whitney $U$ test was used to compare continuous variables. A linear regression analysis was used to examine the correlation between titres of anti-p53 and titres of ANA. $\chi^{2}$ analysis was used to compare the differences in frequencies, with $\mathrm{P}<0.05$ considered to be stastically significant between the groups.

\section{RESULTS}

Distribution of anti-p53 titres in the enrolled patients

Figure 1 illustrates the distribution of anti-p53 in each group of patients enrolled in the present study. Six of 40 (15.0\%) patients with $\mathrm{AIH}$, one of $41(2.4 \%)$ patients with PBC, four of eight (57\%) patients with $\mathrm{AIH} / \mathrm{PBC} \mathrm{OS}$, and four of $10(40 \%)$ patients with HCC were positive for anti-p53, while none of the five patients with PSC and none of the $10 \mathrm{NHC}$ had anti-p53. The prevalences of anti-p53 in patients with $\mathrm{AIH}$ or $\mathrm{AIH} / \mathrm{PBC} \mathrm{OS}$ were significantly higher compared with those with $\mathrm{PBC}(15.0 \%$ versus $2.4 \%[\mathrm{P}=0.0443] ; 50.0 \%$ versus $2.4 \%[\mathrm{P}<0.0001]$, respectively). The specificity of anti-p53 in patients with $\mathrm{AIH}$ or $\mathrm{AIH} / \mathrm{PBC}$ OS was $97.8 \%$. The overall titre in the six AIH patients with anti-p53 was lower than that in the four $\mathrm{AIH} / \mathrm{PBC}$ OS patients with anti-p53, although not significantly $(2.35 \pm 0.83 \mathrm{U} / \mathrm{mL}$ versus $3.88 \pm 2.04 \mathrm{U} / \mathrm{mL} ; \mathrm{P}=0.1100)$. The mean titre in the $\mathrm{AIH} / \mathrm{PBC}$ OS patients with anti-p53 was almost equivalent to that in the four HCC patients with anti-p53 $(3.88 \pm 2.04 \mathrm{U} / \mathrm{mL}$ versus $3.72 \pm 1.64 \mathrm{U} / \mathrm{mL} ; \mathrm{P}=0.9900$ ). In contrast, the titre of anti-p53 in one $\mathrm{PBC}$ patient who was positive for anti-p53 was far lower than that in the AIH patients who were positive for anti-p53.

\section{Comparison of clinical appearance between the AIH groups} seropositive and seronegative for anti-p53

Table 1 summarizes the demographic factors of patients with $\mathrm{AIH}$ seropositive and seronegative for anti-p53. The mean age at entry in $\mathrm{AIH}$ patients positive for anti-p53 was younger than that in $\mathrm{AIH}$ patients negative for anti-p53, although the difference was not 
TABLE1

Comparison of demographic factors between patient groups with autoimmune hepatitis seropositive and seronegative for anti-p53

\begin{tabular}{|c|c|c|c|}
\hline & \multicolumn{2}{|c|}{ Anti-p53 } & \multirow[b]{2}{*}{$\mathbf{P}$} \\
\hline & $\begin{array}{l}\text { Positive } \\
(n=6)\end{array}$ & $\begin{array}{c}\text { Negative } \\
(n=34)\end{array}$ & \\
\hline Age, years, mean \pm SD & $49.7 \pm 15.5$ & $59.1 \pm 15.7$ & 0.1064 \\
\hline Sex, male/female, $\mathrm{n} / \mathrm{n}$ & $0 / 6$ & $2 / 32$ & 0.5422 \\
\hline $\begin{array}{l}\text { Onset patterns (acute/chronic/ } \\
\text { fulminant), } \mathrm{n} / \mathrm{n} / \mathrm{n}\end{array}$ & $1 / 5 / 0$ & $7 / 24 / 3$ & 0.5192 \\
\hline Concurrent autoimmune disease & $4(66.7)$ & $13(38.2)$ & 0.1940 \\
\hline Progression to hepatic failure & $0(0)$ & $5(14.7)$ & 0.3153 \\
\hline $\begin{array}{l}\text { Development of hepatocellular } \\
\text { carcinoma }\end{array}$ & $0(0)$ & $1(2.9)$ & 0.6705 \\
\hline $\begin{array}{l}\text { Efficacy of immunosupressive } \\
\text { treatment }\end{array}$ & $3 / 3(100)$ & $26 / 28(92.9)$ & 0.6322 \\
\hline Relapse rate & $0(0)$ & $8(23.5)$ & 0.1840 \\
\hline
\end{tabular}

Data presented as $n(\%)$ unless otherwise indicated

TABLE 2

Comparison of laboratory and histological findings between groups of patients with autoimmune hepatitis seropositive and seronegative for anti-p53

\begin{tabular}{lccc}
\hline & \multicolumn{2}{c}{ Anti-p53 } & \\
\cline { 2 - 3 } & Positive $(\mathbf{n}=6)$ & Negative $(\mathbf{n}=\mathbf{3 4})$ & $\mathbf{P}$ \\
\hline ALT, U/L & $492 \pm 508$ & $294 \pm 372$ & 0.5615 \\
T-Bil, mg/dL & $2.7 \pm 4.5$ & $3.3 \pm 4.9$ & 0.3987 \\
IgG, mg/dL & $2913 \pm 848$ & $2837 \pm 871$ & 0.5752 \\
Titres of ANA $\geq 1: 160$, & $2(33.3)$ & $22(64.7)$ & 0.1481 \\
$\quad \mathrm{n}(\%)$ & & & \\
HAl score & $13.2 \pm 2.3$ & $14.4 \pm 3.9$ & 0.2986 \\
\hline
\end{tabular}

Data presented as mean $\pm \mathrm{SD}$ unless otherwise indicated. ALT Alanine aminotransferase; ANA Antinuclear antibodies; HAI Heaptitis Activity Index; IgG Immunoglobulin G; T-Bil Total bilirubin

statistically significant. All of the AIH patients positive for anti-p53 were female, while two of 34 (5.9\%) AIH patients negative for antip53 were male. AIH patients seropositive for anti-p53 tended to have a lower prevalence of progression to hepatic failure, a lower rate of relapse, and a higher frequency of concurrent autoimmune diseases such as autoimmune thyroiditis, Sjögren's syndrome and rheumatoid arthritis compared with AIH patients seronegative for anti-p53. There was no significant difference in the onset pattern of the disease between the groups. Only one AIH patient negative for anti-p53 developed HCC. The responses to immunosuppressive treatments were almost equivalent between the groups.

Table 2 compares laboratory and histological data between the groups of patients with $\mathrm{AIH}$ seropositive and seronegative for antip53. AIH patients with anti-p53 tended to have lower titres of ANA than those without anti-p53. There were no significant differences in laboratory data including serum ALT, T-Bil, and IgG levels between the groups of $\mathrm{AIH}$ patients seropositive and seronegative for anti-p53. HAI scores in AIH patients with anti-p53 were almost equivalent to those in AIH patients negative for anti-p53.

Comparison of clinical appearance between the AIH/PBC OS groups seropositive and seronegative for anti-p53

As shown in Table 3, patients with AIH/PBC OS seropositive for antip53 tended to be younger at entry than those seronegative for antip53. Of the AIH/PBC OS patients with anti-p53, one was male. One $\mathrm{AIH} / \mathrm{PBC} \mathrm{OS}$ patient positive for anti-p53 developed HCC. The efficacy of corticosteroid was almost equivalent between the groups. There were no significant differences in laboratory data including serum T-Bil, ALT, ALP, IgM and IgG levels, and titres of ANA and
TABLE 3

Comparisons of demographic, laboratory and histological findings between the groups of patients with autoimmune hepatitis/primary biliary cirrhosis overlap syndrome seropositive and seronegative for anti-p53

\begin{tabular}{lccc}
\hline & \multicolumn{2}{c}{ Anti-p53 } & \\
\cline { 2 - 3 } & Positive (n=4) & Negative (n=4) & $\mathbf{P}$ \\
\hline Age, years & $53.5 \pm 5.3$ & $62.3 \pm 14.8$ & 0.3749 \\
Sex, male/female, $\mathrm{n} / \mathrm{n}$ & $1 / 3$ & $0 / 4$ & 0.2850 \\
Development of HCC & $1(25.0)$ & $0(0)$ & 0.2850 \\
Efficacy of & $2 / 3(66.7)$ & $3 / 4(75.0)$ & 0.8091 \\
$\quad$ immunosuppressive & & & \\
$\quad$ treatment, n/n (\%) & & & \\
T-Bil, mg/dL & $1.6 \pm 1.2$ & $3.9 \pm 6.3$ & 0.8839 \\
ALT, U/L & $98 \pm 91$ & $189 \pm 261$ & 0.5614 \\
ALP, U/L & $840 \pm 739$ & $674 \pm 426$ & 0.7715 \\
Immunoglobulin M, mg/dL & $423 \pm 135$ & $560 \pm 250$ & 0.1465 \\
Immunoglobulin G, mg/dL & $3874 \pm 885$ & $2816 \pm 1163$ & 0.2454 \\
AMA (index) & $74.2 \pm 56.9$ & $71.4 \pm 32.7$ & $>0.9999$ \\
Titres of ANA $\geq 1: 160, \mathrm{n}(\%)$ & $3 / 4(75.0)$ & $4 / 4(100)$ & 0.2850 \\
HAl score & $14.5 \pm 1.9$ & $14.5 \pm 1.3$ & 0.8817 \\
\hline
\end{tabular}

Data presented as mean $\pm S D$ unless otherwise indicated. ALT Alanine aminotransferase; ALP Alkaline phosphatase; AMA Antimicrobial antibodies; ANA Antinuclear antibodies; HAl Histological Activity Index; HCC Hepatocellular carcinoma; T-Bil Total bilirubin

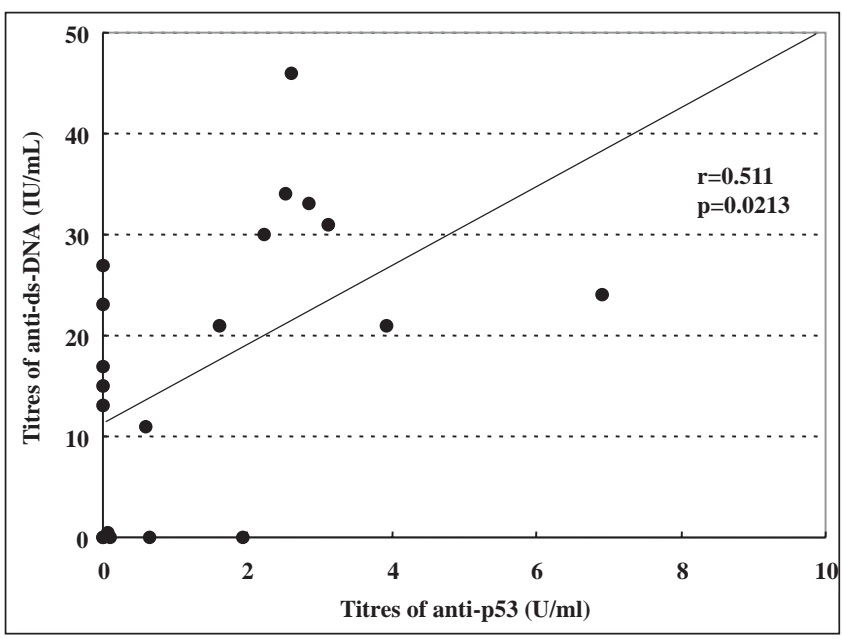

Figure 2) Relationship between titres of anti-p53 and those of antidoublestranded DNA (anti-ds-DNA) in patients with autoimmune hepatitis or autoimmune hepatitis/primary biliary cirrhosis overlap syndrome

AMA between the groups. HAI scores in AIH/PBC OS patients who were seropositive for anti-p53 were almost the same as those in AIH/ PBC OS patients who were seronegative for anti-p53.

Relationship between titres of anti-ds DNA and antibodies to p53 Figure 2 illustrates the correlation between titres of anti-ds DNA and antibodies to $\mathrm{p} 53$ in patients with $\mathrm{AIH}(\mathrm{n}=16)$ or $\mathrm{AIH} / \mathrm{PBC} \mathrm{OS}$ $(n=4)$. The titres of anti-ds DNA in these patients significantly correlated with those of anti-p53 ( $\mathrm{r}=0.511 ; \mathrm{P}=0.0213)$.

Expression of $\mathrm{p} 53$ protein and caspase- 3 in liver tissue p53 expression in liver tissue was examined using immunohistochemical techniques in five patients with AIH seropositive for anti-p53. None of these patients expressed $\mathrm{p} 53$ protein in liver tissue.

On the other hand, caspase- 3 was detected in the livers of four of seven $(57.1 \%) \mathrm{AIH}$ or $\mathrm{AIH} / \mathrm{PBC}$ OS patients with anti-p53, while 
two of five $(40 \%)$ AIH patients without anti-p53 were positive for caspase-3 in the liver (Figure 3), indicating that the emergence of anti-p53 was independent of the expression of caspase- 3 in the liver.

\section{DISCUSSION}

In the present study, we demonstrated that the prevalence of anti-p53 in patients with $\mathrm{AIH}$ or $\mathrm{AIH} / \mathrm{PBC} \mathrm{OS}$ was significantly higher than in patients with $\mathrm{PBC}$, and that patients with $\mathrm{AIH}$ or AIH/PBC OS seropositive for anti-p53 had moderate titres while only one patient with PBC seropositive for anti-p53 had a low titre. These data may imply that the emergence of anti-p53 discriminates $\mathrm{AIH}$ or $\mathrm{AIH} / \mathrm{PBC} \mathrm{OS}$ from $\mathrm{PBC}$. Liver damage in patients with $\mathrm{AIH}$ or $\mathrm{AIH} / \mathrm{PBC} \mathrm{OS}$ occurs through cell-mediated cytotoxicity (22). In contrast, liver damage in PBC is caused primarily by cholestasis (17). Therefore, circulating anti-p53 in patients with $\mathrm{AIH}$ or $\mathrm{AIH} / \mathrm{PBC}$ OS may be a secondary hallmark of autoimmune inflammation and stress (15).

It was of interest that the emergence of anti-p53 in patients with $\mathrm{AIH}$ or $\mathrm{AIH} / \mathrm{PBC} \mathrm{OS}$ was associated with anti-ds DNA in the present study. Antibodies to ds-DNA are frequently present in the sera of patients with AIH (23) as well as in sera of patients with SLE. Herkel et al (24) documented that anti-p53 recognized damaged DNA in patients with SLE. The findings described above suggest that DNA damage may result in the production of anti-p53 in patients with $\mathrm{AIH}$ or $\mathrm{AIH} / \mathrm{PBC} \mathrm{OS}$. It was notable that autoantibodies to the C-terminal domain of the $\mathrm{p} 53$ protein were more closely associated with antibodies to DNA (24).

Some autoantibodies have peculiar biochemical or immunological characteristics, while other autoantibodies can play crucial roles in the prediction of concomitant autoimmune diseases (25), prognosis (26) or the development of malignant transformations $(8,27)$. AIH patients with anticentromere antibodies (ACA) have significantly lower IgG levels than those without ACA (25). On the other hand, the presence of autoantibodies to F-actin (28) or soluble liver antigen (29) is likely to predict poor prognosis including progression to hepatic failure or requirement for liver transplantation. Autoantibodies to asialoglycoprotein receptor seemed to be frequently associated with relapse in patients with $\mathrm{AIH}$ (30). We previously reported a high incidence of HCC development in patients with hepatitis C-related chronic liver disease seropositive for ACA (27). The present study showed a trend toward a lower prevalence of progression to hepatic failure and a lower rate of relapse in $\mathrm{AIH}$ patients with anti-p53 than in those without anti-p53, suggesting that the emergence of anti-p53 appeared to be a favourable prognostic serological marker in patients with AIH. However, the emergence of anti-p53 did not forecast the development of HCC in patients with $\mathrm{AIH}$. We also failed to determine specific biochemical and immunological characteristics of $\mathrm{AIH}$ or $\mathrm{AIH} / \mathrm{PBC}$ OS patients seropositive for anti-p53, except for the correlation between anti-ds DNA and anti-p53.

We hypothesized that the presence of anti-p53 might reflect the severity of apoptosis in liver tissues and, accordingly, examined caspase-3 expression in the liver of patients with $\mathrm{AIH}$ or $\mathrm{AIH} / \mathrm{PBC}$ OS. However, the emergence of anti-p53 was independent of apoptosis in the liver of those patients.

The accumulation of $\mathrm{p} 53$ protein as a result of the gene mutation is likely to produce circulating anti-p53 in patients with malignant disease (3). We previously analyzed the relationship between the expression of IMPs in liver tissues and circulating anti-IMPs in the sera of patients with HCC (8). In that report, we documented that IMPs were detected in the liver tissue of all HCC patients with anti-IMPs, suggesting that the autoantibodies to IMPs are produced through an antigen-driven immune mechanism. However, the expression of p53 protein in the liver tissue was not observed in any AIH patients with anti-p53 in the present study. Thus, the postulated mechanism of antip53 production in patients with $\mathrm{AIH}$ or $\mathrm{AIH} / \mathrm{PBC}$ OS may be different from that in patients with malignant diseases. Further examination will be required to clarify this phenomenon.

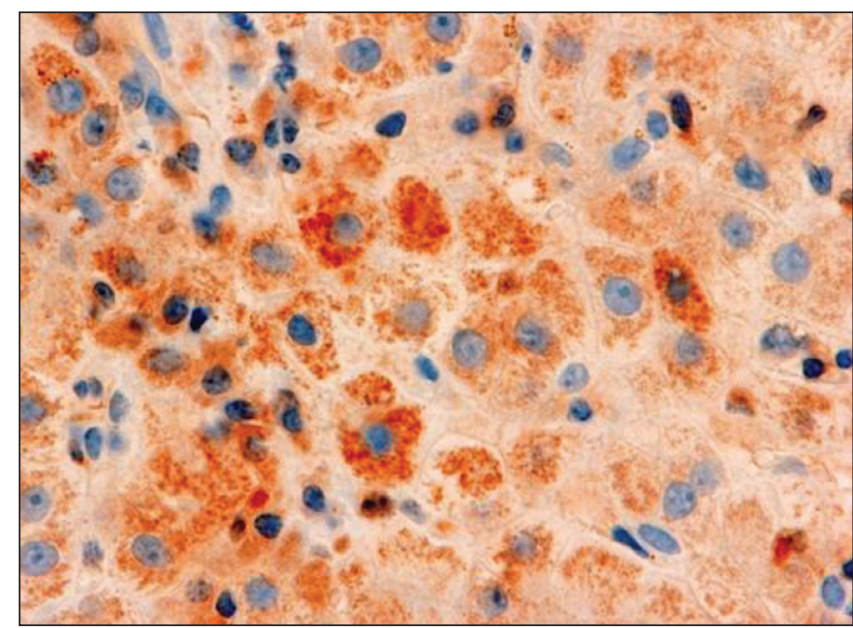

Figure 3) Immunohistochemical detection of caspase-3 in liver tissue. Counterstaining was performed with hematoxylin. Original magnification $\times 200$

\section{CONCLUSION}

The presence of anti-p53 in the sera of patients with autoimmune liver disease was likely specific for AIH or AIH/PBC OS, although the sensitivity of anti-p53 in patients with $\mathrm{AIH}$ was comparatively low. Anti-p53 may be a favourable prognostic hallmark in patients with $\mathrm{AIH}$. The emergence of anti-p53 in patients with $\mathrm{AIH}$ or $\mathrm{AIH} / \mathrm{PBC}$ OS was associated with anti-ds DNA, suggesting that DNA damage might play an important role in the production of anti-p53 in patients with $\mathrm{AIH}$ or $\mathrm{AIH} / \mathrm{PBC}$ OS.

\section{REFERENCES}

1. Hollstein M, Sidransky D, Vogelstein B, Harris CC. P53 mutation in human cancers. Science 1991;253:49-53

2. Hinds PW, Finlay CA, Quartin RS, et al. Mutant p53 DNA clones from colon carcinomas cooperate with rats in transforming primary rat cells: A comparison of the "hot spots" mutant phenotypes. Cell Growth Differ 1990;1:571-80.

3. Soussi T. p53 antibodies in the sera of patients with various types of cancer: A review. Cancer Res 2000;60:1777-88.

4. Craford LV, Pim DC, Bulbrook RD. Detection of antibodies against cellular protein $\mathrm{p} 53$ in sera from patients with breast cancer. Int J Cancer 1982;30:403-8

5. Schlichtholz B, Tredaniel J, Lubin R, Zalcman G, Hirsch A, Soussi T. Analyses of p53 antibodies in sera of patients with lung carcinoma define immunodominant regions in the p 53 protein.

Br J Cancer 1994;69:809-16.

6. Volkmann M, Müller M, Hofmann WJ, et al. The humoral immune response to p53 in patients with hepatocellular carcinoma is specific for malignancy and independent of the $\alpha$-fetoprotein status. Hepatology 1993;18:559-65.

7. Himoto T, Kuriyama S, Zhang JY, Chan EKL, Nishioka M, Tan EM. Significance of autoantibodies against insulin-like growth factor II mRNA-binding proteins in patients with hepatocellular carcinoma. Int J Oncol 2005;26:311-7.

8. Himoto T, Kuriyama S, Zhang JY, et al. Analyses of autoantibodies against tumor-associated antigens in patients with hepatocellular carcinoma. Int J Oncol 2005;27:1079-85.

9. Shiota G, Kishimoto Y, Suyama A, et al. Prognostic significance of serum anti-p53 antibody in patients with hepatocellular carcinoma. J Hepatol 1997;27:661-8.

10. Kovacs B, Patel A, Hershey JN, Dennis GJ, Kirschfink M. Antibodies against p53 in sera from patients with systemic lupus erythematosus and other rheumatic diseases. Arth Rheum 1997;40;980-5.

11. Mariette X, Sibilia J, Delaforge C, et al. Anti-p53 antibodies are rarely detected in serum of patients with rheumatoid arthritis and Sjögren's syndrome. J Rheumatol 1999;26:1672-5. 
12. Miura Y, Yazawa N, Tamaki Z, et al. Anti-p53 antibodies in patients with dermatomyositis/polymyositis. Clin Rheumatol 2007;26:1328-31.

13. Fenton CL, Patel A, Tuttle RM, Francis GL. Autoantibodies to p53 in sera of patients with autoimmune thyroid disease. Ann Clin Lab Sci 2000;30:179-83.

14. Di Cesare E, Previti M, Lombardo F, et al. Serum anti-p53 autoantibodies in patients with type 1 diabetes. Ann Clin Lab Sci 2001;31:253-8.

15. Herkel J, Modrow JP, Bamberger S, et al. Prevalence of autoantibodies to the $\mathrm{p} 53$ protein in autoimmune hepatitis. Autoimmunity 2002;35:493-6.

16. Alvarez F, Berg PA, Bianchi FB, et al. International Autoimmune Hepatitis Group Report: Review of criteria for a diagnosis of autoimmune hepatitis. J Hepatol 1999;31:929-38.

17. Degott C, Zafrani ES, Callard P, et al. Histopathological study of primary biliary cirrhosis and the effect of ursodeoxycholic acid treatment on histological progression. Hepatology 1999;29:1007-12

18. Chazouilleres O, Wendum D, Serfaty L, et al. Primary biliary cirrhosis-autoimmune hepatitis overlap syndrome: Clinical features and responses to therapy. Hepatology 1998;28:296-301.

19. LaRusso NF, Wiesner RH, Ludwig J, MacCarty RL. Current concepts. Primary sclerosing cholangitis. N Engl J Med 1984;310:899-903.

20. Lubin R, Schlichtholz B, Bengoufa D, et al. Analysis of p53 antibodies in patients with various cancers define B-cell epitopes of human p53: Distribution on primary structure and exposure on protein surface. Cancer Res 1993;53:5872-6.

21. Knodell RG, Ishak KG, Black WC, et al. Formulation and application of a numerical scoring system for assessing histological activity in asymptomatic chronic active hepatitis. Hepatology 1981;1:431-5.

22. Czaja AJ, Manns MP. Advances in the diagnosis, pathogenesis, and management of autoimmune hepatitis. Gastroenterology 2010;139:58-72.

23. Czaja AJ, Morshed SA, Parveen A, Nishioka M. Antibodies to single-stranded and double-stranded DNA in antinuclear antibodypositive type-1-autoimmune hepatitis. Hepatology 1997;26:567-72.

24. Herkel J, Mimran A, Erez N, et al. Autoimmunity to the p53 protein is a feature of systemic lupus erythematosus (SLE) related to anti-DNA. J Autoimmun 2001;17:63-9.

25. Himoto T, Murota M, Yoneyama $\mathrm{H}$, et al. Clinical characteristics of patients with autoimmune hepatitis seropositive for anticentromere antibody. Hepatol Res 2010;40:786-92.

26. Czaja AJ. Autoantibodies as prognostic markers in autoimmune liver disease. Dig Dis Sci 2010;55:2144-61.

27. Himoto T, Nakai S, Kinekawa F, et al. Clinical characteristics of patients with hepatitis $\mathrm{C}$ virus-related chronic liver disease seropositive for anticentromere antibody. Dig Dis Sci 2009;54:360-8.

28. Czaja AJ, Cassani F, Cataleta M,Bianchi FB. Frequency and significance of antibodies to actin in type 1 autoimmune hepatitis. Hepatology 1996;24:1068-73.

29. Ma Y, Okamoto M, Thomas MG, et al. Antibodies to conformational epitopes of soluble liver antigen define a severe form of autoimmune liver disease. Hepatology 2002;35:658-64.

30. McFarlane IG, Hegarty JE, McSorley CG, McFarlane BM, Williams R. Antibodies to liver-specific protein predict outcome of treatment withdrawal in autoimmune chronic active hepatitis. Lancet 1984;2:954-6. 


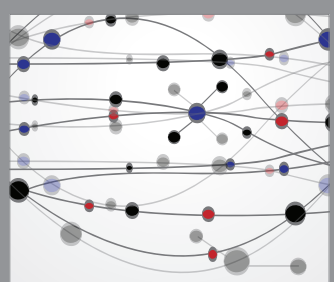

The Scientific World Journal
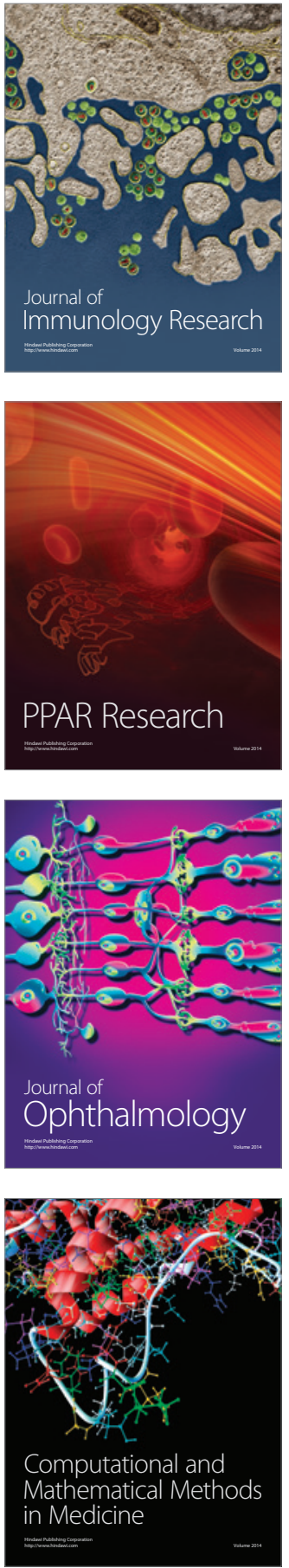

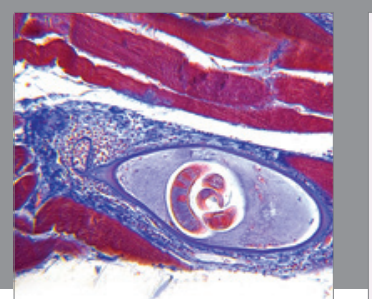

Gastroenterology Research and Practice

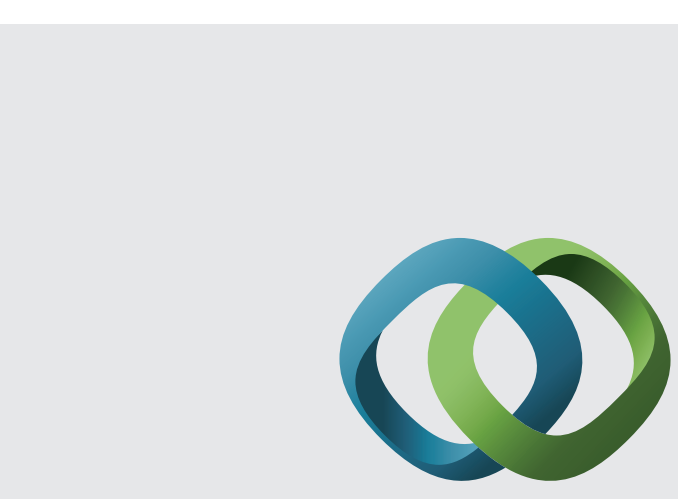

\section{Hindawi}

Submit your manuscripts at

http://www.hindawi.com
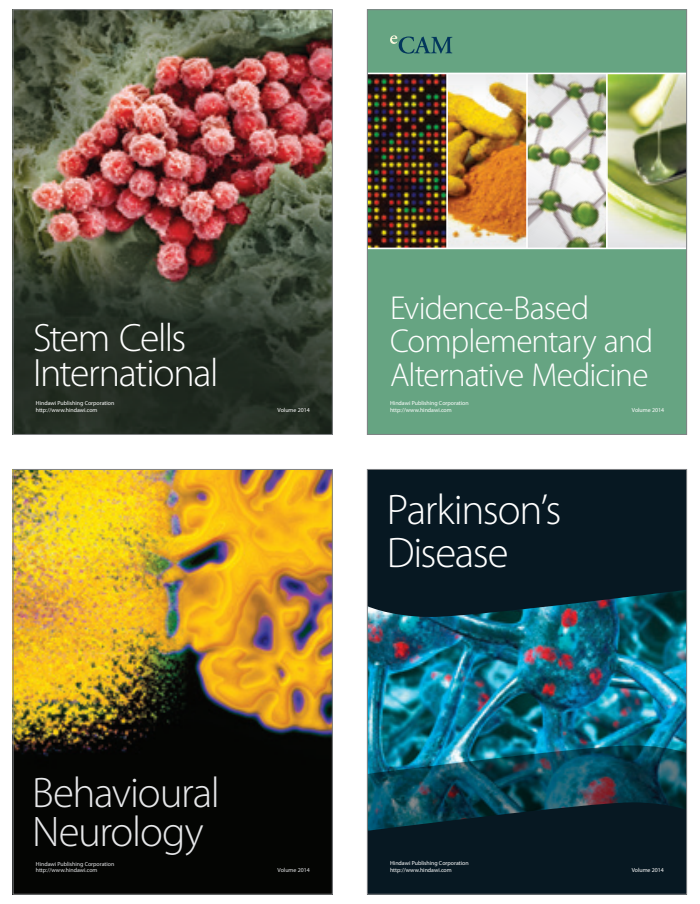
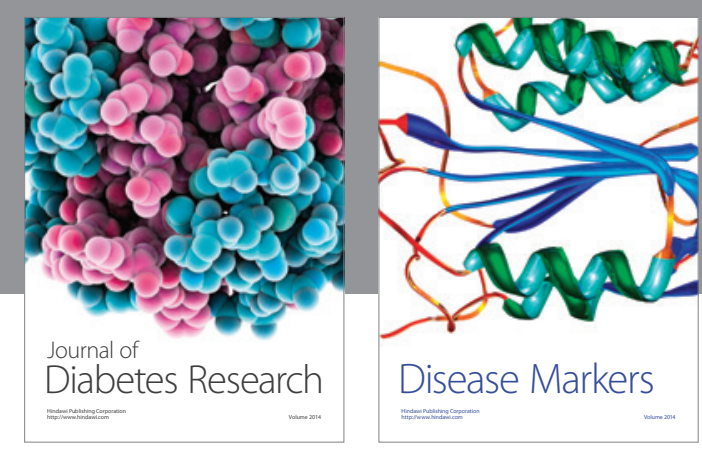

Disease Markers
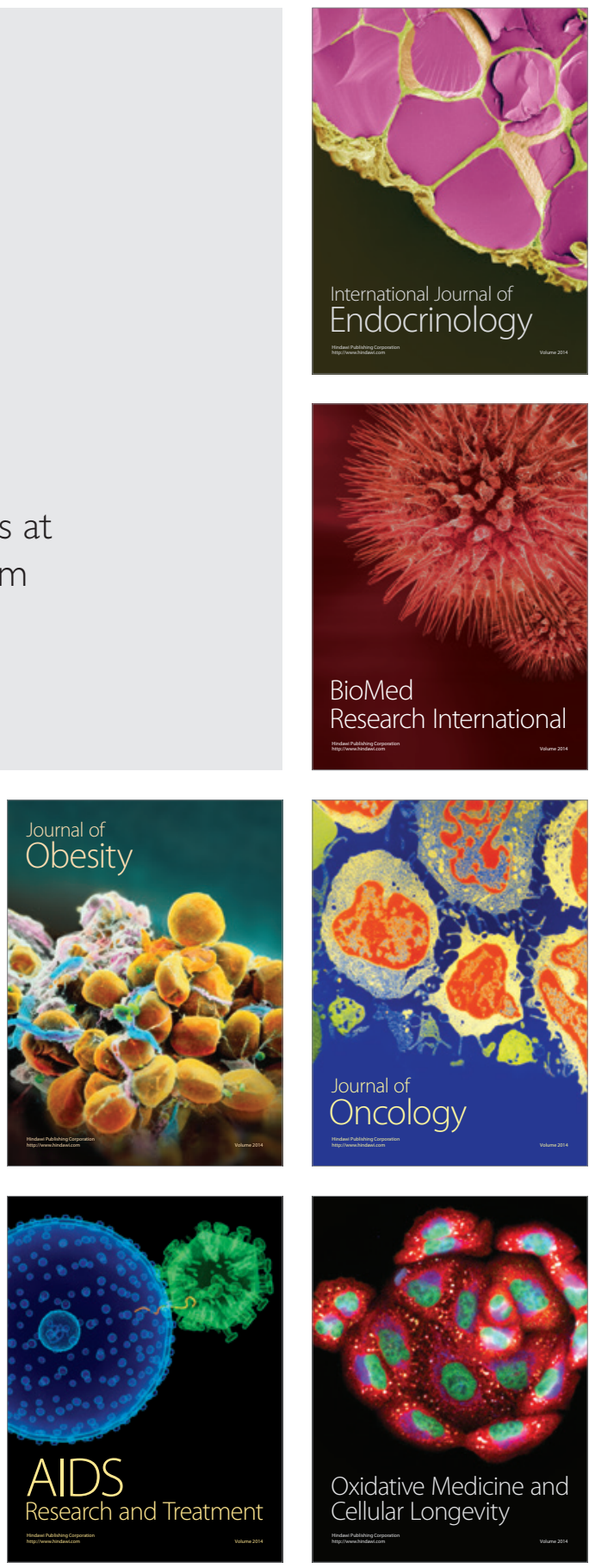